15. огд нов . . ероятный облик вооруженной борьбы будущего [ екст] / . . огд нов // оенн мысльь. - 2003. - № 12. - . 2-7.

16. льчук. . уч сний $\mathrm{cm} \mathrm{н} і$ тенденції розвитку н ціон льних інтересів кр їни в г лузі безпеки [ екст] / . . льчук // ук і оборон . - 2003. № 2. - . 14-21

17. оробьев . . кие войны грозят н $\boldsymbol{M}$ в будущем [ екст] / . . оробьев // р сня везд.1995. — № 167 (2134). — 23 np.

18. ечуров. некоторых спект $х$ военных реформ в з рубежных стр н $х$ [ екст] / . ечуров // рубежное военное обозрение. - 2004. — № 2. — . 4-9.
19. улин . . новой концепции войны [ екст]/ . . улин // оенн я мысль. - 1997. - № 2. - . 13-16.

20. листр тов . . вопросу о форм $х и$ способ х вооруженной борьбы [екст] / . . листр тов// оенн я мысль. - 2003. 一№ 12. - . 45-54.

дійщл до ред кції 3.11.2010 p.

ецензент: доктор технічних н ук, ст рший н уковий співробітник . . убков, к демія сухопутних військ імені гетьм н етр г йд чного, ьвів.

\title{
. . фимов
}

$m$ тья посвящен н лизу современных взглядов н орг низ цию боевой и опер тивной подготовки соединений, , основных тенденииях в путях подготовки войск исходя из современных угроз н иион льной безоп сности госуд рств и ко лиций. сновное вним ние сосредоточено н изменениях в систем х боевой подготовки, исходя из приобретенного опыт во время выполнения боевых з д ч в госл вии, фг нист не и рке, определен необходимость их изучения с иелью тр нсформ иии системы подготовки ухопутныхвойск ооруженных ил кр ины (

лючевые слов : боев я и опер тивн я подготовк соединений, ч стей и подр зделений передовых стр н мир и

, „ссиметричные” угрозы, нетр диционные военные опер ции, ухопутные войск ооруженных ил кр ины, тр нсформ ция системы боевой подготовки.

\section{TENDENCIES OF DEVELOPMENT OF FORMS AND WAYS OF ARMED STRUGGLE BASED ON THE EXPERIENCE OF ONGOING MILITARY CONFLICTS: EXPERINCE FOR TRAINING OF TACTICAL SECTION}

\author{
G.V. Yefimov
}

The article regards the analysis of main tendencies of development of forms and ways of armed struggle, characteristic for wars and ongoing military conflicts, forms of weapon and equipment exploitation (especially new models), experience of their employment in combat environment and their impact on the results of combat actions with the purpose of improvement of basic forms and ways of tactical section specialists training. It defines the necessity of their study for further transformation of training system of Army of the Ukrainian Armed Forces.

Keywords: military conflict, regional and local war, tendencies of development of forms and ways of armed struggle, "asymmetric" threats, non-conventional military operations, cadets training system transformation.

\section{7:355}

\section{. . $\mathrm{p}$ вченко, . . ксіюк}

ціон льний університет оборони кр ӥни, иїв

\begin{abstract}
пропонов но підхід ефективного структурув ння зн нь в інформ ційній інтелекту льній системі.
лючові слов : предст влення зн нь, інформ ційн інтелекту льн систем , інформ ційний ресурс.
\end{abstract}

ост новк проблеми. ослідження пок з ли, що однією з н йбільш в жливих проблем, 3 якою доводиться зіштовхув тись при обробці зн нь бо при побудові систем, 3 снов них н зн ннях, є предст влення зн нь. е пов'яз но з тим, що предст влення зн нь в ост точному підсумку обумовлює х р ктеристики інформ ційної інтелекту льної системи. ри виборі н лежного способу 
предст влення зн нь можн уникнути непотрібного ускл днення системи й вирішити б г то пит нь.

ким чином, однією з н йбільш в жливих проблем, 3 якою доводиться зіштовхув тися при обробці зн нь бо побудові систем, з снов них н зн ннях, $\epsilon$ предст влення зн нь.

н ліз публік цій. икон ний н ліз існуючих принципів предст влення зн нь в інформ ційних інтелекту льних систем х дозволив зробити висновок про необхідність удоскон лення існуючих підходів щодо структурув ння зн нь. е обумовлено розвитком п р тної скл дової, прогр много з безпечення т новими можливостями інформ ційних технологій вз г лі.

етою ст тті $\epsilon$ розроблення підходу до ефективного структурув ння зн нь в інформ ційній інтелекту льній системі.

\section{сновН ч стин}

укове обгрунтув ння розробленої в $[1,2]$ концепції використ ння інформ ційного ресурсу системи дист нційного н вч ння зіткнулося 3 н ступними труднощ ми. еобхідно зн йти т ку структуру інформ ційному ресурсу $\left\{V^{*} \cap D^{*}\right\} \in \Omega^{*}$, при якій якість н вч льного процесу відповід л б з д ним вимог м, ч с н вч ння і в ртість зменшув лися [2]. ле отрим ти н літичні бо лгоритмічні з лежності

$$
\begin{gathered}
E\left(V^{*} \cup D^{*}, F_{i n}^{E}, F_{o n}^{E}\right) ; T\left(V^{*} \cup D^{*}, F_{i n}^{T}, F_{o n}^{T}\right) ; \\
C\left(V^{*} \cup D^{*}, F_{i n}^{C}, F_{o n}^{C}\right)
\end{gathered}
$$

де $\left\{v_{j}^{*}\right\} \in V^{*} \quad$ множин елементів моделі інформ ційного ресурсу;

$\left\{d_{k}^{*}\right\} \in D^{*}$ - множин зв'язків між елемент ми моделі інформ ційного ресурсу;

$j, k \in N-$ н тур льні числ ;

$\Omega$ - інформ ційний ресурс;

$\Omega^{*}$ - модель інформ ційного ресурсу;

$E\left(V^{*} \cup D^{*}, F_{i n}^{E}, F_{o n}^{E}\right)$ - цільов функція якості Н Вч ННя;

$$
\begin{aligned}
& T\left(V^{*} \cup D^{*}, F_{i n}^{T}, F_{o n}^{T}\right)-\text { ч с н вч ння; } \\
& C\left(V^{*} \cup D^{*}, F_{i n}^{C}, F_{o n}^{C}\right)-\text { витр ти н створення }
\end{aligned}
$$
системи т їі експлу т цію;

$E_{*} \quad-\quad 3$ д не зн чення якості н вч ння; $F_{\text {in }}^{E,}, F_{\text {on }}^{E,}, \quad-$ внутрішні т зовнішні ф ктори відповідно,

неможливе через скл дність досліджув ного процесу.

ропонується н ступн н уков гіпотез : якість н вч льного процесу зросте, ч с н н вч нНя і в ртість зменш ться з умови простого викл дення н вч льного м тері лу (інформ ційного ресурсу) т мінім льної його втр ти в процесі структурув ння при предст вленні в системі дист нційного н вЧ ння (1).

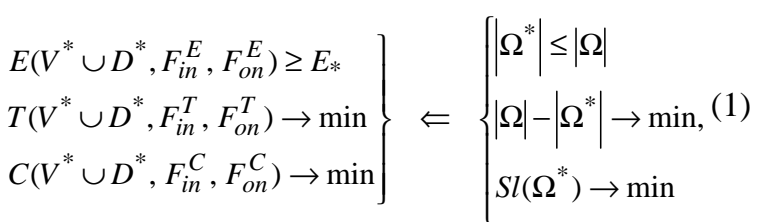

де $\operatorname{Sl}\left(\Omega^{*}\right)$ - пок зник скл дності структури інформ ційного ресурсу.

$$
\text { цьому вип дку н уков проблем }
$$

ефективного предст влення зн нь в інформ ційній системі, сформульов н в роботі [2], прийм $є$ вигляд, предст влений н рис. 1.
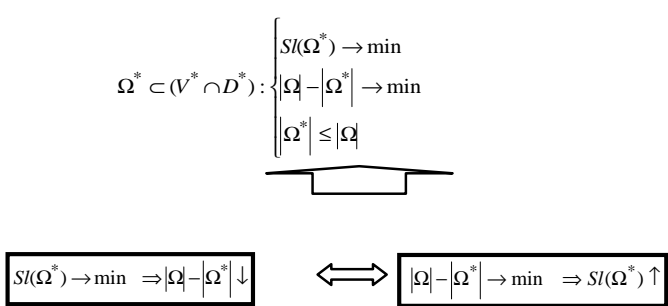

uc. 1. уков проблем ефективного предст влення зн нь в інформ ційній системі

е обумовлено тим, що структуру як сукупність множини елементів і множини зв'язків (відносин) між ними можн н літично оцінити 3 пок зником скл дності, отже, перевести проблему в площину теорії скл дності. с ме, потрібно структурув ти інформ ційний ресурс т к, щоб скл дність отрим ної структури бул мінім льною при його незн чній втр ті.

ншими слов ми, н вч ти потрібно просто, без 3 йвого ускл днення н вч льного м тері лу $\left(S l\left(\Omega^{*}\right) \rightarrow \min \right), \quad$ т кож мінімізув ти втр ти зн нь при їх структурув нні $\left(|\Omega|-\left|\Omega^{*}\right| \rightarrow \min \right)$.

метою док зу н укової гіпотези було проведено пед гогічний експеримент, суть якого поляг $€$ в н ступному: створено три експеримент льні групи слух чів. лух ч м було пост влене 3 вд ння придб ти зн ння т уміння 3 дисципліни « снови технології дист нційного н вч ння» (36 годин 3 г льного н в нт ження, 3 них під керівництвом викл д ч 18 годин для очної форми н вч ння).

1- груп ( 1) - н вч л сь дист нційно 3 експеримент льним курсом.

2- груп ( 2) - н вч л сь дист нційно 3 тр диційним курсом.

3-я груп ( 3) - н вч л сь 3 очно 3 
тр диційним курсом.

ксперимент льний дист нційний курс був розроблений н основі пр ктичних рекоменд цій, які отрим ні н основі гіпотези.

ксперимент льн груп 1 - це безпосередній об'єкт пед гогічного експерименту. ід ч с підготовки слух чів, 3 огляду $\mathrm{H}$ специфіку контингенту групи, використовув лось, здебільшого с мостійне н вч ння 3 отрим ними м тері л ми (з допомогою мережевої $\mathrm{T}$ кейсової технологій). ндивіду льні бо групові консульт ції (семін ри) н д в лися (з потребою) для пояснення незрозумілого м тері лу. пед гогічному експерименті бр ло уч сть 260 осіб професорськовикл д цького скл ду, студентів т н укових пр цівників, із них 69 осіб групи 1, 148 осіб групи

2, т 43 особи групи 3 . онтроль т оцінюв ння теоретичних зн нь і пр ктичних умінь слух чів здійснюється протягом процесу н вч ння 3 результ т ми усних відповідей, демонстр ції пр ктичних умінь і викон ння с мостійних т індивіду льних з вд нь, 3 н слідк ми модульних тест ційних контрольних.

поч тку формув льного експерименту 3'ясов но ступінь теоретичних зн нь слух чів всіх груп щодо зн нь, умінь і н вичок викл д ч тьютор . роцес здійснено шляхом попереднього тестового випробув ння. езульт т дослідження предст влено н рис. 2.

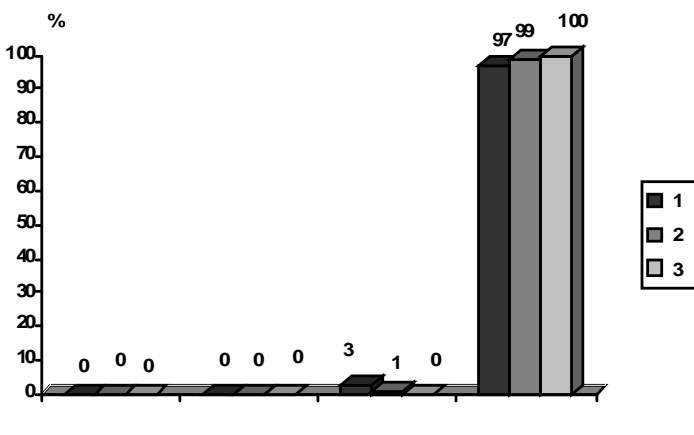

uc. 2. і гр м розподілення слух чів 3 рівнями теоретичних зн нь

з метою ст тистичної перевірки ф кту рівності теоретичної обізн ності слух чів усіх груп, під ч с вступного контролю використ но критерій $\chi^{2}$ [3]. результ ті порівняння трьох груп поп рно отрим но $\chi_{1,2}^{2}\left(\begin{array}{ll}1 \mathrm{~T} & 2\end{array}\right), \chi_{1,3}^{2}\left(\begin{array}{ll}1 \mathrm{~T} & 3\end{array}\right), \chi_{2,3}^{2}\left(\begin{array}{ll}2 \mathrm{~T} & 3\end{array}\right)$.

формов ні в контексті н лізу гіпотези:

0- Н явність зн чних зн нь т умінь слух чів груп;

1 - відсутність зн чних зН нь т умінь слух чів груп.

изн чення ст тистики критерію $\chi^{2}$ проведено 3 формулою [3]. ісля підст новки зн чень у формулу отрим но величину ст тистики критерію для рівнів зн нь слух чів груп:

$$
\begin{gathered}
\chi_{1,2}^{2}=3,81-1 \mathrm{~T} \quad 2 ; \chi_{1,3}^{2}=3,79-1 \mathrm{~T} 3 \\
\chi_{2,3}^{2}=1,79-2 \mathrm{~T} 3 .
\end{gathered}
$$

ри рівні зн чущості $\alpha=0,05$ критичне зн чення для трьох ступенів вільності дорівнює 7,815 [3]. бр хов ні зн чення ст тистики у всіх вип дк х менші критичного зн чення 7,815, отже, відповідно до пр вил ухв лень рішень, отрим ні зн чення спростовують нульову гіпотезу й д ють підст ви для прийняття гіпотези 1 , як стверджує відсутність зн чних відмінностей у рівнях обізн ності слух чів груп. прикінці експерименту проведено підсумкове тестове випробув ння т звітув ння про викон ння індивіду льних з вд нь.

трим ні результ ти тестового випробув ння рівня теоретичної підготовки слух чів груп у г лузі дист нційного н вч ння н ведено н рис. 3 .

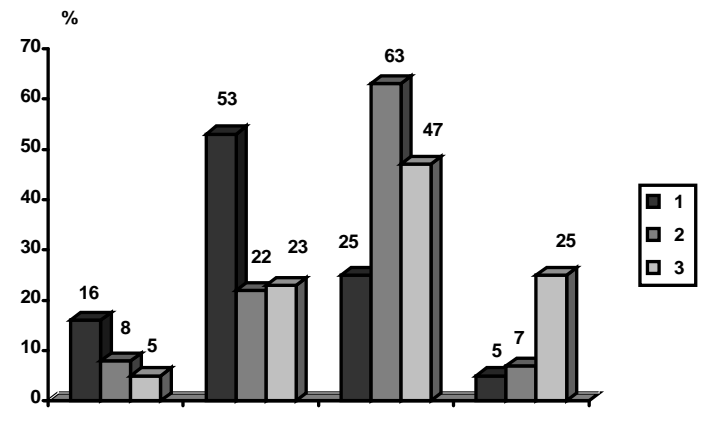

\section{uc. 3. езульт ти тестового випробув ння зн нь слух чів}

ким чином, вн слідок проведеної підготовки отрим но результ ти, що свідч ть про ефективність н вч ння 3 експеримент льним курсом дист нційного н вч ння. к, кількість слух чів, що володіють високим рівнем теоретичних зн нь, зросл в контрольних груп х ( 2 і 3) н 8\%, в експеримент льній групі - н $16 \%$. омітне збільшення $з$ фіксов но в дост тньому рівні теоретичних зн нь слух чів контрольних груп 2 н 43\%, 3 - н 22\%, в експеримент льної групи слух чів 1 - н 53\%. ідбувся зн чний ст тистичний перерозподіл н низькому т середньому рівнях.

икорист ємо критерій $\chi^{2}$ для перевірки істинності гіпотез, визн чимо гіпотези:

0- результ т підготовки 3 експеримент льним в рі нтом підготовки не відрізняється якістю від рівня підготовки слух чів 3 контрольним в рі нтом підготовки;

1 - результ т підготовки 3 експеримент льним в рі нтом підготовки позитивно вплив $є$ Н якість рівня підготовки слух чів порівняно 3 тр диційним в рі нтом підготовки. 
икористовуємо формулу критерію $\chi^{2}$ [3]. озр хунки критерію $\chi^{2}$, які об'єдн ні для ст тистичного вимірюв ння груп: $\chi_{1,2}^{2}=9,96-1$ $\mathrm{T} \quad 2 ; \chi_{1,3}^{2}=11,74-1 \mathrm{~T} \quad 3 ; \chi_{2,3}^{2}=5,82-2 \mathrm{~T} \quad 3$.

г д ємо, що при рівні зн чущості $\alpha=0,05$ критичне зн чення для трьох ступенів вільності дорівнює 7,815 [3]. еличин Зн чення ст тистики $\chi_{2,3}^{2}=5,82$ (порівняння контрольних груп) менш 3 величину критичного зн чення 7,815. е д $\epsilon$ підст ви, згідно з пр вил ми ухв лення рішень [3], визн ти істинність гіпотези 0 , відповідно до якої нем є суттєвої різниці в якості отрим них зн нь між слух ч ми контрольних груп. р ховуючи, що величин зн чення ст тистики $\chi_{1,2}^{2}=9,96 \quad$ т $\chi_{1,3}^{2}=11,74$ (порівняння експеримент льної і контрольних груп відповідно) перевищує величину критичного зн чення 7,815, керуючись пр вил ми ухв ли рішень, відхиляємо нульову гіпотезу о $\mathrm{i}$ прийм ємо 3 істину льтерн тивну гіпотезу 1 .

ким чином, ст тистичне опр цюв ння д них підтверджує пр вильність гіпотези 1, згідно з якою результ т підготовки групи 13 експеримент льним курсом дист нційного н вч ння позитивно вплив $є$ н рівень сформов ності зн нь, відмінності в якості зн нь підготовки слух чів групи порівняно з якістю зн нь контрольних груп 2 т 3 є суттєвими.

орівняння всіх груп 3 рівнем пр ктичної підготовки до 3 пров дження дист нційного н вч ння гр фічно зобр жено н рис. 4.

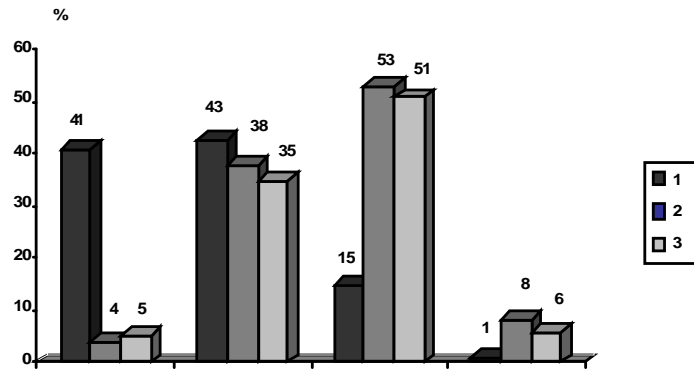

uc. 4. езульт т пр ктичної підготовленості слух чів до 3 пров дження дист нційного н вч ння в н вч льному процесі езульт т підсумкового контролю 3 підготовкою слух чів експеримент льної і контрольних груп гр фічно предст влено н рис. 5.

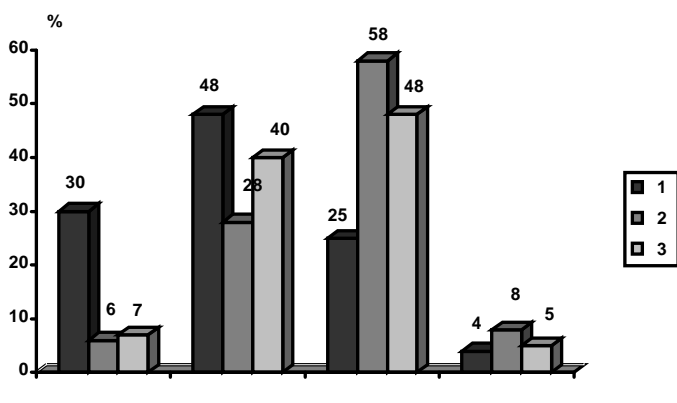

uc. 5. езульт т підсумкового контролю груп

\section{ИсН ОВ К И}

ким чином, експеримент льний курс дист нційного н вч ння дозволив підготув ти $78 \%$ слух чів н дост тньому т високому рівні зн нь т умінь. ля порівняння, в інших груп х цього рівня досягли $34 \%$ т $47 \%$ відповідно. обто цей курс близько н $40 \%$ ефективніший ніж інші. кож виявлено ф кт зменшення ч су н усвідомлення відповідного н вч льного м тері лу в порівнянні 3 3 очною формою н вч ння.

\section{писок літер тури}

1. р вченко . . онцепція структурув ння інформ ційного ресурсу системи дист нційного н ви ння / р вченко . ., ксіюк. . // уч сні інформ ційні технології у сфері безпеки $m$ оборони. - .. 2009. - № 1(4). - . 6-11.

2. ксіюк . . роблем ефективного використ ння інформ ційного ресурсу системи дист нційного н вч ння / ксіюк.. . // уч сні інформ ційні технологї̈ у сфері безпеки т оборони. - .. 2009. - № 3(6). - . 49-52.

3. ронштейн . . пр вочник по м тем тике для инженеров и уч щихся втузов / . . ронштейн, . . емендяев. - .. $\quad$ ек, 1986. -544 c.

дійщл до ред кції 29.10.2010 р.

ецензент: доктор технічних н ук, професор . . p б ш, ціон льний університет оборони кр їни, иїв.

. . $\mathrm{p}$ вченко, . . ксиюк

редложен подход эффективного структуриров ния зн ний в информ ционной интеллекту льной системе. лючевые слов : предст вление зн ний, информ ционн я интеллекту льн я систем, информ ицонный ресурс.

\section{APPROACH TO KNOWLEDGE REPRESENTATION IN INFORMATION SYSTEM}

Y.V. Kravchenko, O.G. Oksiyuk

Approach to effective structuring of knowledge in information intellectual system is proposed.

Keywords: knowledge representation, information intellectual system, information resource. 